\title{
Fluctuation of Patchouli Oil Price and Its Effect On Patchouli Aceh Production and Productivity
}

\author{
Yusnidar $^{1}$, Irma Susanti ${ }^{1}$, Jamilah $^{1 *}$, Ellyta Effendy ${ }^{1}$, Romano $^{2}$ \\ ${ }^{1}$ Department of Master of Agribusiness, Faculty of Agriculture, Universitas Malikussaleh, Aceh, Indonesia \\ ${ }^{2}$ Department of Agribusiness, Faculty of Agriculture, Universitas Syiah Kuala, Aceh, Indonesia \\ *Corresponding author E-mail: jamilah@unimal.ac.id
}

Manuscript received 15 August 2021; revised 1 Sept 2021; accepted 15 Sept 2021. Date of publication 4 Nov 2021

\begin{abstract}
The study aims to determine the price fluctuations and their effects on patchouli farm and patchouli oil production in Aceh Province. The Research Method used survey method with an explanatory research as an approach. The location of the study was conducted in Aceh Province, in Aceh Jaya Regency and Aceh Barat Regency. The fluctuations of patchouli oil price have an affect to the motivation of farmers in developing patchouli farming. Farmers in the study location tend to do patchouli farming when the price of patchouli oil is high, instead farmers do not do patchouli farming when the price of patchouli oil decreases. The fluctuations in patchouli oil prices determined by the quality of patchouli oil and market demand have a dominant influence on the development of production and the productivity of patchouli in Aceh. Standardization of patchouli oil quality at the agro-industry level will increase the price of patchouli oil at the farmers level and increase farmers' income. The price of patchouli oil fluctuates depends on Patchouli Alcohol (PA) levels. This is the main reason for traders at the district and provincial levels to reduce prices at the farm level. Aceh Patchouli has oil quality that qualified with basic export standards. But there is still a need for cultivation techniques and better application of refining technology to improve the quality of patchouli oil at the farmer level so that it can increase the price of patchouli oil at the farmer level while simultaneously increasing the income and welfare of farmers. The phenomenon of patchouli oil price fluctuations in high has an important role in the development of patchouli oil agro-industry.
\end{abstract}

Keywords: Fluctuation, Price, Production, Patchouli Oil.

\section{Introduction}

Aceh has a potential for patchouli development because Aceh has a tropical climate that suitable for patchouli farming. Aceh patchouli plantations are generally developed by farmers with diverse cropping patterns [1]. The higher oil quality content contains around $2.5-5 \%$ oil, it is more in demand in both the domestic and international markets. There are three superior Aceh patchouli varieties with high oil content and quality, like Lhokseumawe, Tapak Tuan, and Sidikalang. The Aceh Patchouli Protection Community Forum (FMPNA) stated in 2015 patchouli production in the four production centers (West Aceh, Aceh Jaya, South Aceh and Gayo Lues Regency) was $500 \mathrm{~kg} /$ month, while market demand reached 2 tons / month. Each district produces patchouli oil from the average $200 \mathrm{~kg} / \mathrm{month}$. Each patchouli farmer in Aceh has 1 hectare until 12 hectares of farming area. However, the potential of patchouli is estimated can not optimally [2] [3]. The efforts of the regional government in developing Aceh patchouli through the expansion of patchouli planting areas have not provided maximum results. Aceh's patchouli productivity is low . Even the price of patchouli oil tends to fluctuate. Patchouli productivity is still relatively low, the average yield is only $214 \mathrm{~kg}$ per ha per year with $1-2 \%$ oil content from dry matter. Furthermore stated the level of patchouli productivity from year to year continued decrease [4]. The productivity level below $150 \mathrm{~kg}$ of oil / ha reaches an area of $45 \%$ of the total patchouli planting area in Indonesia. The development of patchouli planting areas in Aceh was not followed by an increase in productivity, quality and price stability. In 2015, Aceh's patchouli productivity was $321 \mathrm{~kg} /$ ha. Patchouli Alcohol (PA) quality is below $31 \%$ and prices always fluctuate. The low production of most patchouli is caused by the application of technology does not have attraction to environmental aspects. Besides that the pattern of planting is very diverse. Many studies in several patchouli planting locations showed, some patchouli planting is planted in locations with less suitable land based on growing requirements. The low level of productivity is probably caused by several factors including the drought season, low cultivation skills and poor seed quality [5]. 


\section{Literature Review}

\subsection{Characteristics and Quality of Aceh Patchouli}

Patchouli is Aceh's leading export commodity and the quality of Aceh's patchouli oil occupies the best quality in the international market. Patchouli oil distillation (extraction) business is carried out on a small and medium scale, but patchouli oil processing is still at the upstream level and only uses traditional methods. The patchouli processing business still encounters many obstacles related to yield, the length of the extraction process and the low quality of patchouli oil extraction. The average yield of patchouli oil extraction is around $1-2 \%$ with a very long extraction time of about 7-10 hours. The use of conventional extraction technology is one of the causes of low industrial yields. The Caritas International Institute for Czeh Republic stated that Aceh's patchouli product could be a potential product because it has a distinctive aroma and is not owned by any region [6] [7] [8].

Patchouli oil is used, among other things, as a raw material, mixing material and fixative (perfume binder) in the perfume, pharmaceutical and cosmetic industries as well as food and beverages as well as a fragrance for scarves, carpets and woven goods [9] [10]. Aceh patchouli or pogostemon cablin benth has an oil content ranging from 2.5 to 3.3 percent. Therefore, patchouli in Aceh is above the world average quality. The quality of patchouli oil is strongly influenced by the content of PA which is the main component in patchouli oil, and is required in international trade of $30 \%$. Some of the obstacles in the patchouli oil industry include the low quantity of oil recovery (rendement), varying oil quality, discontinuous production and fluctuating prices, thereby reducing the competitiveness of the national patchouli oil industry [1] [11].

\subsection{Added Value and Business Feasibility}

Added value is the added value of a commodity due to the functional input applied to the commodity in question. The functional input is a process of changing shape, moving places, or storing. Several important variables related to value added analysis are conversion factor which refers to the number of outputs produced from one unit of input; labor coefficient factor which refers to the amount of direct labor needed to process; and the value of the product which refers to the value of the output produced from one unit of input [12] [13].

\section{Methods}

\section{Research Location}

The research location was determined purposively, are in West Aceh District and Aceh Jaya Regency as the center of Aceh patchouli production according to indicators of land area, production and patchouli productivity [7] [14].

\section{Research Methods}

This study used an explanatory as research approach with survey methods. Data collection techniques are construct by observation, interviews, and documentation. Identification of Aceh patchouli and patchouli oil production patterns at patchouli farming and patchouli oil agro-industry, patchouli oil price fluctuations and their effects on patchouli and patchouli oil production and its relationship to market demand was taken by qualitative and quantitative descriptive as an approaches [15] [16] [17].

\section{Results and discussion}

Aceh Patchouli was developed in the form of smallholder plantation business with mixed garden patterns. Generally patchouli plants are developed in high-land areas and far from the location of village. Planting is done by an intercropping system, farmers are planted together with other crops such as palm oil, cocoa, and others. This is not much different from the results of research in Asahan District (North Sumatra - Indonesia) that the profile of patchouli agroindustry in the area is the scale of small businesses, farmers' business owners, simple processing technology, crop patterns tend to intercropping and patchouli exploitation is only another income.

The environmental conditions (agroclimate) was a primary affect to the content and quality of patchouli oil. Planting in an open land allows the content of patchouli essential oil to reach 5\%, while in places or land with too many protective trees only 4.66\% (Mangun, 2005). The management of patchouli cultivation intensively and the environment grows that fill the requirements, like a temperatures of $24-28{ }^{\circ} \mathrm{C}$, rainfall $2000-3500 \mathrm{~mm}$ per year or humidity $>75 \%$, soil texture crumb, loose and many humus, and soil height reaches $50-400 \mathrm{~m}$ above sea level. Plants is grow in the low-lands have high oil content, low PA (pathchouly alcohol), and compared with the highlands, low oil content but high PA. Patchouli Alcohol (PA) quality of patchouli oil is below 31\% and prices always fluctuate (Rosman, 2012). Patchouli essential oil levels vary, depending on the variety. Patchouli aceh (Pogostemon cablin), because it does not have flower, the oil content is high (2.5 - 5\%). Java patchouli (P. heyneanus) due to the flowering plant, low oil content (0.5 - 1.5\%). While the patchouli (P. hortensis), the oil content is $0.5-1.5 \%$, and this type is less favored in the market.

Patchouli plants is a raw material of essential oils. Plants that produce essential oils are estimated at 150-200 species of plants, including those belonging to the Pinaceae, Labrate, Compositae, Lauraceae, Myrtaceae, and Umbelliferaceae families. Essential oils can be sourced from every part of the plant, such as leaves, flowers, fruit, seeds, stems, skin, and roots. For patchouli plants, the essential oil is taken from the leaves. Patchouli processing into patchouli oil is generally done by farmers with a salary system in the processing industry. In a planting area of $625 \mathrm{~m} 2,6 \mathrm{~kg}$ of patchouli oil can be obtained. The utilize of refining equipment in processing will determine the quality of patchouli oil and will affect the price of patchouli oil. The price of patchouli oil from the results of processing with stainless steel distillers ranges from 440,000 IDR / kg, while patchouli oil produced from a simple refiner can be sold at a price of 420,000 IDR / kg. The use of stainless steel construction materials, can produce patchouli oil that fill quality standard. The price of patchouli oil in the domestic market is influenced by the price of patchouli oil in the international market. Indonesia supplied $80-90 \%$ of patchouli oil on the international market. Patchouli oil export volume has increased every year by $6 \%$ over the 10 years ago and the demand of patchouli oil in the international market each year is between 1200-1400 tons and the volume tends to increase, while the available production only reaches 1,000 tons per year. This is due to the price of patchouli oil in the international market has slightly increase annually.

The quality of patchouli oil is not same and do not have standardized because the selling price of patchouli oil at the farm level relatively cheap even though the demand for patchouli oil in the international market is relatively increasing every year. The price of patchouli oil fluctuates depends on Patchouli Alcohol (PA) levels. This is the main reason for traders at the district and provincial levels to reduce prices at the farm level. Aceh Patchouli has oil quality that qualified with basic export standards. But there is still a need for cultivation techniques and better application of refining technology to improve the quality of patchouli oil at the farmer level so that it can increase the price of patchouli oil at the farmer level while simultaneously increasing the income and welfare of farmers. The phenomenon of patchouli oil price 
fluctuations in high has an important role in the development of patchouli oil agro-industry. Export opportunities and high quality patchouli oil should be the main focus for local governments and exporters to develop local resources with an agro-industrial approach so as to increase the income and welfare of farmer households, the introduction of new types of plants is very important for increasing and stabilizing farmers' income. The development of agro-industry small and medium enterprises, especially essential oils is very important and strategic in terms of employment, equity and economic growth and in order poverty alleviation.

In 2015, the price of patchouli oil at the district level was relatively stable. On the other hand, prices at the farm level and sub-district collectors tend to cultivate, especially in August to November. This shows that price increases at the district level are not well integrated at the level of farmers and sub-districts. This condition is not beneficial at the level of farmers and traders (Figure 1)

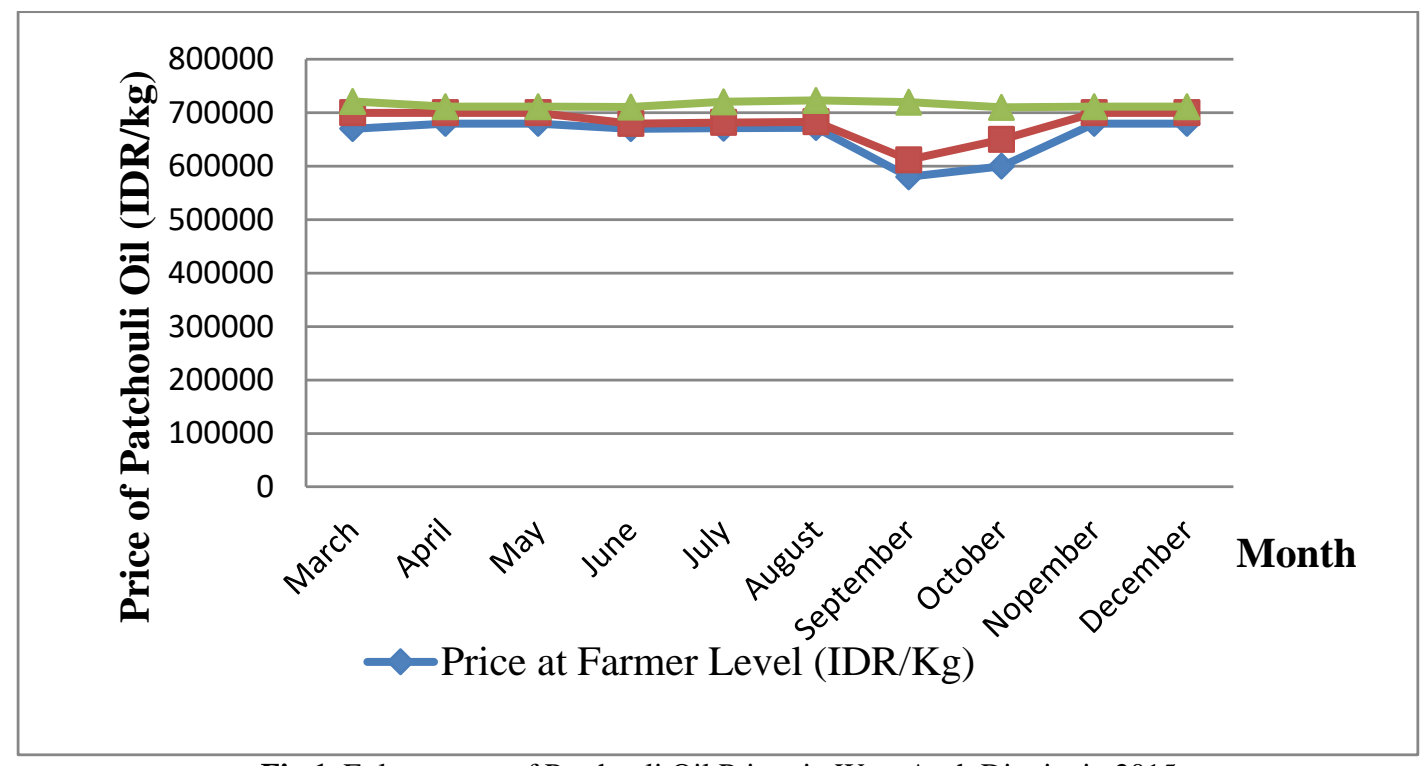

Fig 1. Enlargement of Patchouli Oil Prices in West Aceh District in 2015

In 2020, there was a downward trend in the price of patchouli oil in Aceh Province in April 2020. The trend has a decline sharp occurred in April to June. Furthermore, the price decline slightly to December 2020, whereas the price at the farm level remained relatively. 600,000 IDR / kg (Figure 2).

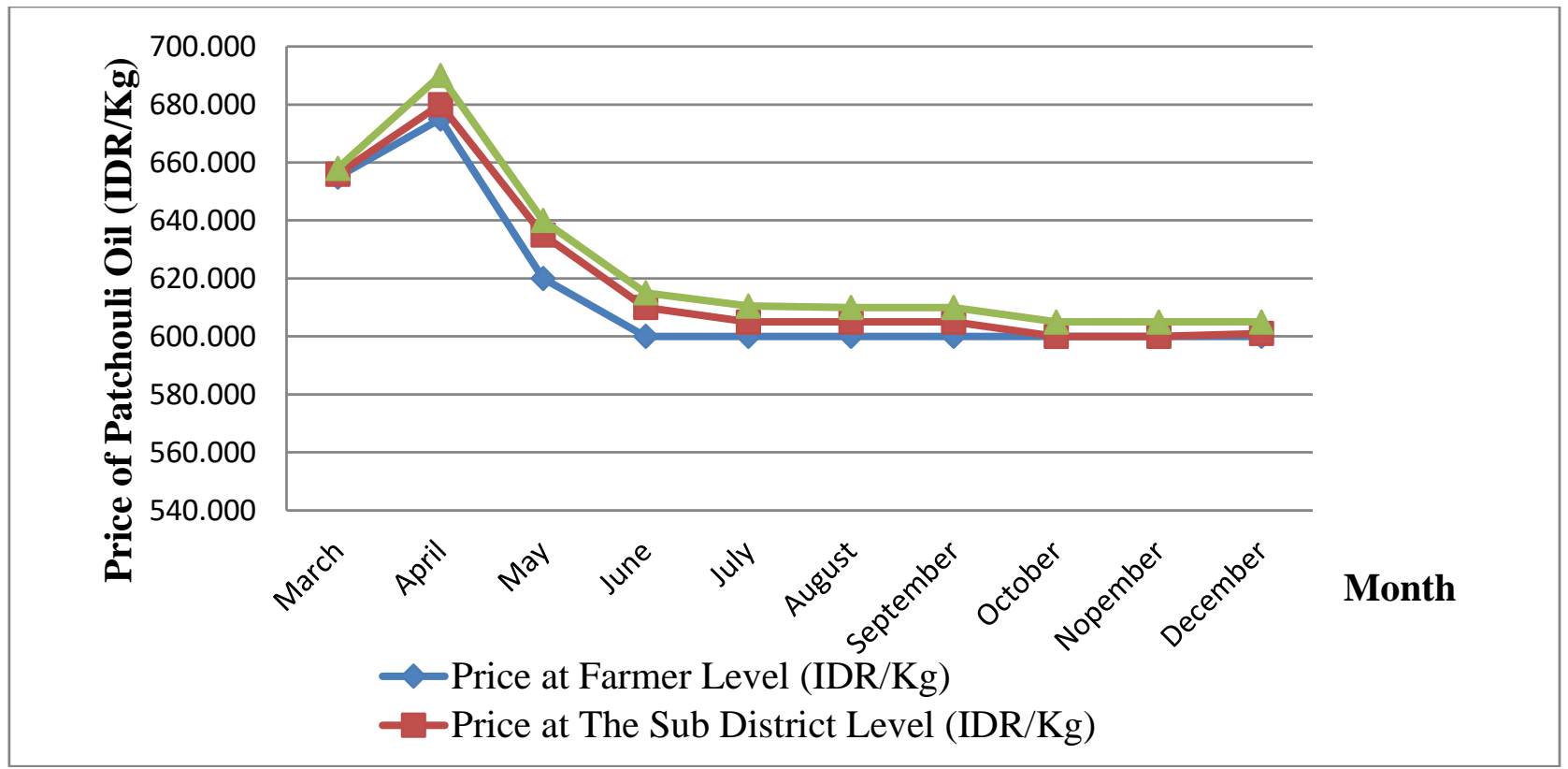

Fig 2. Development of Patchouli Oil Prices in West Aceh District in 2020

The fluctuations of the patchouli oil price based on farmers' decision to cultivate patchouli. This will affect the availability of patchouli oil in the international market. Winarti (2005) stated the reason for farmers to cultivate patchouli for several reason, but the most dominant is that patchouli is considered more profitable. The second biggest reason is because it follows other farmers who have first planted patchouli. According to Willock et al. in Ondersteijn et al. (2003) decisions taken by farmers to try something new are not only influenced by economic factors but also socio-economic and psychological factors.

The potential of patchouli oil ranges from $20 \mathrm{~kg} /$ ha to $35 \mathrm{~kg} /$ ha. The biggest patchouli oil potential in Jaya District is $35 \mathrm{~kg} / \mathrm{ha}$, but patchouli productivity is relatively low $(<150 \mathrm{~kg} / \mathrm{ha})$. Most patchouli growth is in the Pasie Raya District. Patchouli potential in this district reaches $34 \mathrm{~kg} /$ ha (Table 1). According to Pujiharti et al. (2000) increasing production through appropriate cultivation techniques, patchouli oil repair and development of patchouli planting to areas that have bright prospects seen from the level of land suitability and climate and marketing. 
Table 1. Development of Patchouli Area, Production and Productivity in Aceh Jaya Regency, 2013-2017

\begin{tabular}{crrrr} 
Year & $\begin{array}{c}\text { Plantation Area } \\
(\mathrm{Ha})\end{array}$ & $\begin{array}{c}\text { Production } \\
(\text { Ton })\end{array}$ & $\begin{array}{c}\text { Productivity } \\
(\mathrm{Kg} / \mathrm{Ha})\end{array}$ & \multicolumn{2}{c}{$\begin{array}{c}\text { Farmers } \\
(\mathrm{KK})\end{array}$} \\
\hline 2016 & 500 & 35 & 103 & 1.285 \\
2017 & 500 & 16 & 103 & 611 \\
2018 & 244 & 19 & 107 & 611 \\
2019 & 84 & 43 & 297 & 611 \\
2020 & 198 & 27 & 136 & 611 \\
\hline
\end{tabular}

The potential of plantations can support the economic sector of the people in rural settlements, so that the mixed plantation areas in this region will be maintained. The area of this large plantation area is set at 54,363.04 Ha (19.67\%) while the area of the mixed plantation area is $62,840.89 \mathrm{Ha}(22.73 \%)$. Compared to other plantation crops, patchouli planting area is relatively small at only 201.50 hectares, indicating that patchouli farming is a side activity. Patchouli plant was developed by 878 farmers in all sub-districts in the area of Aceh Barat Regency with a land area of $201.50 \mathrm{ha}$, production of 31.44 tons, and the average productivity of patchouli oil of $240 \mathrm{~kg} / \mathrm{Ha}$ (Forestry and Plantation Service Aceh Barat Regency, 2019 ) This shows that patchouli plants have the potential to be developed which is supported by the availability of land and agro-climates that are in accordance with patchouli cultivation. But the level of productivity of patchouli plants is relatively low. Low productivity level (under $150 \mathrm{~kg}$ of oil / ha) reaches $45 \%$ of total patchouli planting area in Indonesia (Setiawan and Rosman, 2013). The low supply of Aceh patchouli oil is due to; (1) the low yield of patchouli oil obtained, (2) the quality of oil is low and variety due to poor quality control, and (3) the supply of non-continuous products and fluctuating prices (Yuhono, 2014). The fluctuations of patchouli oil price have an affect to the motivation of farmers in developing patchouli farming. Farmers in the study location tend to do patchouli farming when the price of patchouli oil is high, instead farmers do not do patchouli farming when the price of patchouli oil decreases.

The high world demand for essential Indonesian patchouli oil indicates that the Province of Aceh has great potential for patchouli development, which is supported by the availability of plantation land, agro-climate conditions that support the growth and development of patchouli commodities, the support of local governments and international institutions, and the processing of patchouli into patchouli oil relatively easy and can be done by farmers. Increased production and stability of patchouli oil prices will encourage the development of patchouli oil agro-industry and at the same time improve the regional and national economy. Small-scale modern export-oriented agroindustry is the best way to transfer knowledge and technology. States that compared to staple crops, cash crops provide a higher contribution to overall economic growth so that it can help break the cycle of poverty.

\section{Conclusion}

Patchouli oil price fluctuations, which are determined by patchouli oil quality and market demand, have a dominant influence on the development of Aceh's oil production and productivity. The standardization of patchouli oil quality is determined by the refining process and the use of distillers. For this reason, special attention is needed from the government and exporters to develop Aceh patchouli, both at the level of cultivation, processing, and marketing of patchouli oil

\section{References}

[1] R. Widowati, S. Handayani, and I. Lasdi, "AKTIVITAS ANTIBAKTERI MINYAK NILAM ( Pogostemon cablin ) TERHADAP BEBERAPA SPESIES BAKTERI UJI," Pro-Life, vol. 6 Nomor 3, 2019.

[2] E. Sufriadi, H. Meilina, A. A. Munawar, S. Muhammad, and R. Idroes, "Identification of $\beta$-Caryophyllene (BCP) in Aceh patchouli essential oil (PEO) using gas chromatography-mass pectrophotometry (GC-MS)," in IOP Conference Series: Earth and Environmental Science, 2021, vol. 667, no. 1, doi: 10.1088/1755-1315/667/1/012032.

[3] I. Zikri, Agussabti, Indra, S. Kamaruzzaman, E. Susanti, and Mujiburrahmad, "Study on sustainable agriculture and dimension of needs: A case study patchouli farming in Aceh Jaya," in IOP Conference Series: Earth and Environmental Science, 2021, vol. 667, no. 1, doi: 10.1088/1755-1315/667/1/012038.

[4] M. Tahir, D. Riniarti, Ersan, and J. Kusuma, "Genetic and leaf characteristic diversity on 10 mutant progenies of patchouli (Pogostemon cablin) provide insights to selection strategies,” Agrivita, vol. 41, no. 1, 2019, doi: 10.17503/agrivita.v41i1.1908.

[5] E. Thanassoulis, M. Kortelainen, and R. Allen, "Improving envelopment in Data Envelopment Analysis under variable returns to scale," Eur. J. Oper. Res., 2012, doi: 10.1016/j.ejor.2011.10.009.

[6] Harunsyah and M. Yunus, "Process Design Of Patchouli Oil Distillation By Varying Operating Conditions To Increase Yield Of Patchouli Oil," in The Proceedings of The 2nd Annual International Conference Syiah Kuala University 2012 \& The 8th IMT-GT Uninet Biosciences Conference, 2012, vol. 2, no. 2.

[7] R. Junaidy, F. Redha, and I. Sulaiman, "Peningkatan Kadar Alcohol Patchouli Dalam Minyak Improvement of Alcohol Patchouli Level in Patchouli Oil Using," Maj. Biam, vol. 15, no. 1, 2019.

[8] N. Kadkhoda, H. Jafari, and R. M. Ganji, "A numerical solution of variable order diffusion and wave equations," Int. J. Nonlinear Anal. Appl., vol. 12, no. 1, 2020, doi: 10.22075/ijnaa.2021.4652.

[9] D. Rahmayanti, R. A. Hadiguna, S. Santosa, and N. Nazir, "Determining The Profit Margin In 'Patchouli Oil' Supply Chain: A Case Study In Indonesia,” Int. J. Adv. Sci. Eng. Inf. Technol., 2018, doi: 10.18517/ijaseit.8.2.3485.

[10] H. G. Ramya, V. Palanimuthu, and S. Rachna, "An introduction to patchouli (Pogostemon cablin Benth.) - A medicinal and aromatic plant: It's importance to mankind," Agric. Eng. Int. CIGR J., vol. 15, no. 2, 2013.

[11] A. G. Vonna, I. Indra, and A. Nugroho, "Market Analysis of Patchouli Oil in Aceh Jaya Aceh Province," Int. J. Multicult. Multireligious Underst., vol. 7, no. 9, 2020, doi: 10.18415/ijmmu.v7i9.2207.

[12] J. Han, M. Kamber, and J. Pei, Data Mining: Concepts and Techniques. 2012.

[13] N. Y. Dahlan, M. E. A. Mohammed, W. N. A. W. Abdullah, and Z. M. Zain, "Economic feasibility study of a $16 \mathrm{kWp}$ grid connected PV system at Green Energy Research Centre (GERC), UiTM Shah Alam," in BEIAC 2013 - 2013 IEEE Business Engineering and 
Industrial Applications Colloquium, 2013, doi: 10.1109/BEIAC.2013.6560097.

[14] R. Candra Fitrian and A. Sumarno, "Study of the Effect Clay Substitution with Wood Sawdust and Hydroton on Compressive Strength, Density and Water Absorption of Red Brick Case Study of Traditional Red Brick Industry in Singgahan Village," Int. J. Eng. Sci. Inf. Technol., vol. 1, no. 1, 2021, doi: 10.52088/ijesty.v1i1.103.

[15] F. F. Kareem and R. D. Ali, "A topology on a ring part of is-algebra," Int. J. Nonlinear Anal. Appl., vol. 12, no. 2, 2021, doi: 10.22075/ijnaa.2021.5141.

[16] N. Qalby, M. S. Rusli, and E. Anggraeni, "Analysis and design of crowdfunding investment system as financing alternative for patchouli production in Aceh," in IOP Conference Series: Earth and Environmental Science, 2020, vol. 472, no. 1, doi: $10.1088 / 1755-1315 / 472 / 1 / 012041$.

[17] M. Zarebnia and R. Parvaz, “A new approach for solution of telegraph equation,” Int. J. Nonlinear Anal. Appl., vol. 12, no. 1, 2021, doi: 10.22075/ijnaa.2021.4811. 